\title{
The Influence of Employee Self-efficacy, Outcome Expectation and Firm Resources on Intrapreneurial Behaviour: Insight from Ghana
}

\begin{abstract}
By Nina Afriyie*, Lemayon L. Melyoki* \& Mariam Nchimbi ${ }^{ \pm}$
The purpose of this study is to examine the effect of employee perceived selfefficacy on intrapreneurial behaviour among Small and Medium size Enterprises (SMEs). We surveyed 234 employees from SMEs in the fresh fruit juice processing industry in Ghana using a structured questionnaire to obtain data. A statistical data analysis was performed. Our findings show that employees' perceived self-efficacy relates positively to their intrapreneurial behaviour. However, we observed also that self-efficacy was not a sufficient condition for intrapreneurial behaviour to occur. Firm characteristics play a crucial role in the practice of such behaviour. That is, while employees' self-efficacy is a principal determinant of employees' intrapreneurial behaviour, the strength of self-efficacy is enhanced by firm resource. These results have policy implications for the promotion of SMEs in Ghana and similar contexts. The study contributes to knowledge on intrapreneurship in SMEs by pointing out that individual characteristics are not always linear in relation to intrapreneurship. Other factors that enhance these characteristics need to be taken account of. We provide recommendations for policy makers and researchers. (JEL H32, J20, O15)
\end{abstract}

Keywords: Intrapreneurship, Innovation, Self-efficacy, SMEs, Ghana.

\section{Introduction}

Intrapreneurship is considered critical for firms to remain competitive in the market place (Ahmad et al. 2012). Baruah and Ward (2014) assert that intrapreneurship in today's economic environment can be used as a strategy to enhance organizational competitiveness. Intrapreneurship creates a culture that encourages employees to channel the resources of a firm toward development of new products or services (Peng et al. 2010). Thus, through intrapreneurship employees become "change agents" in firms, bringing about new ideas and advocating for implementation of such ideas. This eventually contributes to business growth as it provides an environment that supports and sustains innovation. Intrapreneurship enables the organization to tap into each employee's talent, as well as attracting and retaining most intrapreneurial employees (Vargas-Halabi et al. 2017). By practicing intrapreneurship employees who

\footnotetext{
${ }^{*}$ Lecturer, University of Cape Coast, Ghana.

*Senior Lecturer, University of Dar es Salaam, Tanzania.

${ }^{ \pm}$Senior Lecturer, University of Dar es Salaam, Tanzania.
} 
have innovative ideas referred to as dreamers are able to implement those ideas within the existing organisation rather than create spin-offs (Pinchot 1985).

Intrapreneurship has traditionally been viewed as a phenomenon that could only be practiced in the context of large corporate organisations. As a result, researchers have tended to ignore small and medium size enterprises hence lack of research on how to enhance, develop and promote this phenomenon in the context of small businesses (Carrier 1994, 1996, Antoncic and Hisrich 2001, Bosma et al. 2011, Sijde et al. 2013, Stam and Stenkula 2017). Therefore, the concept has been well embraced by large companies (Urban and Oosthuizen 2009). Large companies such as Sony, Saturn, and Google serve as examples. Thus, the play station inside of Sony and the Saturn inside of general motor are results of intrapreneurial success. Indeed, Google promotes intrapreneurship through its culture of allowing its employees to use 20 percent of their working hours to work in pursuit of their own new ideas. This culture is believed to be the source of Google's success (Schawbel 2013). In like manner, large companies in transitional economies, Africa in particular are embracing intrapreneurship, though at a slower pace (Urban and Oosthuizen 2009). This could be due to fear of change associated with intrapreneurship (Intrapreneurship Conference Report 2017).

According to Amo (2010), intrapreneurship is an individual level concept, where the individuals own traits regarding how they perceive their abilities to identify an opportunity, handle it, and turning that opportunity into fruition is of essence. These human behaviours may be triggered by two expectations (Bandura 1997, 1986). The first relates to the expectations concerning one's ability to perform a particular behaviour, i.e. self-efficacy. The second encompasses the expected outcomes of the particular behaviour. This indicates that a person's self-efficacy as well as the expected outcome, may determine how much effort and persistence he/she shows towards a given task or behaviour. However, research works on intrapreneurship have not considered these two constructs while researching on intrapreneurial behaviour. Considering intrapreneurship from the individual initiated perspective, this study investigates intrapreneurial behaviour from the angle of employees' 1) self-efficacy expectation and 2) outcome expectation. It answers the research question; to what extent does employees' perceived self-efficacy and outcome expectation influence their zeal for intrapreneurship in the presence of firm resource availability?

This paper addresses the intrapreneurship from the individual induced perspective and hence contributes in several ways to the current development of the intrapreneurship field. The paper makes three contributions: 1) contributes knowledge to intrapreneurship in SME 2) contribute knowledge to employee initiated intrapreneurship from a psychological angle; 3) contributes to knowledge on firm resources and intrapreneurship. The rest of the paper is organized as follows: literature review, methodology, research findings and finally discussions and conclusions. 


\section{Literature Review}

\section{Concept of Intrapreneurship}

While 'entrepreneur', has a long and rich history in the literature, the first publication of the term 'intrapreneur' did not occur until the late 1970s and when it was first introduced by Pinchot and Pinchot (1978). Pinchot explains intrapreneurship acts as an innovative and revolutionary, as they break the status-quo and hierarchy in an organisation. Later scholars defined intrapreneurship is similar ways (see Antoncic and Hisrich (2003), Mokaya (2012). In this research, we view intrapreneurship as the process by which individual employees within existing firms take self-starter initiatives to depart from routine ways of doing things within the firm, to act proactively and innovatively dependent on the firm's resources in an agented fashion to advance the firm and make it competitive (Afriyie et al. 2019).

Theoretically, intrapreneurship is entrepreneurship in a different context. This means measuring intrapreneurship applies the same measures as entrepreneurship since the two concepts are not distinct from each other. Antoncic and Hisrich (2003) assert that intrapreneurship is now developed as a more integrative concept based on two predominant streams in previous theory (entrepreneurial orientation and corporate entrepreneurship). They proposed that intrapreneurship should be viewed as a multi-dimensional concept with eight distinct but related components. These are new ventures, new business, product/service innovativeness, process innovativeness, self-renewal, risk taking, proactiveness and competitive aggressiveness. Most of the studies on intrapreneurship have been twisting and turning these eight dimensions as a measure of intrapreneurship. Antoncic and Hisrich (2003) argue that the eight dimensions proposed could also pertain to the same concept of intrapreneurship in terms of the Schumpeterian concept of innovation

From Table 1 this current study argues that all three approaches, are acts of intrapreneurship where employees exhibit their quota to the growth, advancement and competitiveness of the firm using resources available in an agent relationship to bring radical or incremental changes in products, processes and or marketing activities. This is the essence of intrapreneurship in the generic sense. Intrapreneurship is a behavioural outcome. Therefore, any intrapreneurial action is exhibited by the behaviour of individuals in the form of being innovative or proactive. This study focuses on the innovativeness and proactiveness as a measure of employees' intrapreneurial behaviour. This is consistent with Knight (1997) who posits that innovativeness and proactiveness are robust measurements of intrapreneurial behaviour. A considerable number of studies (eg Sijde et al. 2013, Heinonen and Korvela 2014, Taştan and Güçel 2014, North 2015, Gawke et al. 2019) have used innovativeness as a measure of intrapreneurship with all concluding that innovativeness is a key indicator of intrapreneurship. 
Table 1. Overview of Different Conceptualization of Employee Intrapreneurship

\begin{tabular}{|l|l|l|}
\hline \multicolumn{1}{|c|}{ Approach } & \multicolumn{1}{|c|}{ Conceptualization } & \multicolumn{1}{c|}{ Reference } \\
\hline $\begin{array}{l}\text { The } \\
\text { entrepreneurial } \\
\text { approach }\end{array}$ & $\begin{array}{l}\text { Employee intrapreneurship is conceptualise on } \\
\text { the basis of an employee's entrepreneurial } \\
\text { orientation (i.e., proclivity towards } \\
\text { innovativeness, risk taking and personal } \\
\text { initiatives) }\end{array}$ & $\begin{array}{l}\text { Wakkee et al. (2010), Sun and } \\
\text { Pan (2011), Rigtering and } \\
\text { Weitzel (2013), Moriano et al. } \\
\text { (2014), Valsaina et al. (2016) }\end{array}$ \\
\hline $\begin{array}{l}\text { The } \\
\text { intrapreneurial } \\
\text { outcomes } \\
\text { approach }\end{array}$ & $\begin{array}{l}\text { Employee intrapreneurship is conceptualised } \\
\text { as employees' participation in an } \\
\text { organisations intrapreneurship pursuits or a } \\
\text { number of implemented intrapreneurial } \\
\text { initiatives }\end{array}$ & $\begin{array}{l}\text { Bager et al. (2010), Parker } \\
\text { (2011), Stam (2013), Urbano et } \\
\text { al. (2013), Guerrero and Pena- } \\
\text { Legaskue (2013) }\end{array}$ \\
\hline $\begin{array}{l}\text { The } \\
\text { behaviour- } \\
\text { based } \\
\text { approach }\end{array}$ & $\begin{array}{l}\text { Employee intrapreneurship is conceptualise on } \\
\text { the basis of employee activities that contribute } \\
\text { to firm-level intrapreneurship, and more } \\
\text { recently as employees' agenticand } \\
\text { anticipatory behaviours aimed at creating new } \\
\text { businesses for the organisation (i.e. venture } \\
\text { behaviour) and enhancing an organisation's } \\
\text { ability to react to internal and external } \\
\text { advancements (strategic renewal behaviour) }\end{array}$ & $\begin{array}{l}\text { Gawke et al. (2019), Woo } \\
\text { (2018) }\end{array}$ \\
\hline
\end{tabular}

Source: Gawke et al. (2019).

This present study indicates that some of the many dimensions of intrapreneurship proposed in literature are redundant. For example dimensions such as new venture, new business venturing, self-renewal, strategic renewal (eg. Antoncic and Hisrich 2003, Guth and Ginberg 1990, Zahra 1993, Sharma and Chrisman 1999, Schollhammer 1981, Covin and Slevin 19861, 1991), all lead themselves into the broader concepts of innovation. A detailed description of new venture, business venture, and self-renewal could culminate into innovativeness. Such that in discussing about innovation and its various activities; such as new creation in terms of process, product, technology, venturing new market identifying new market niche and opportunities (Schumpeter 1939, Drucker 1985) all these dimensions fall in line.

Proactiveness has also been established in literature as an important behaviour aspect of intrapreneurship. Pro-activeness relates to pioneering and initiatives taking in pursuing new opportunities or entering new markets (Lumpkin and Dess 1996) and describes an act in anticipation of action to be taking. Morris (2001) defines organisations which are intrapreneurial as ones that proactively seek to grow and is not constrained by the resources it currently possesses. Proactiveness has been shown to be positively associated with intrapreneurial intentions (Crant 1996) and behaviour. A firm is said to be intrapreneurial when its employees are always taking initiatives, tackling issues head on, anticipating and preventing problem and are change oriented (Bateman and Crant 1993). Becherer and Maurer (1999) found that entrepreneurs who exhibited a proactive behaviour were inclined to adopt more business opportunities.

A study conducted by Vargas-Halabi (2017) among University professionals in private organisation in Costa Rica found that proactivity is a higher level construct of intrapreneurship. Sijde et al. (2013) found a similar view that proactiviness such as initiative taking, as a measure of intrapreneurship. Gawke 
et al. (2019) also assert that employees may proactively combine existing resources to create a new product in an intrapreneurship firm. In addition, competitive aggressiveness and risk-taking in a more in depth direction are skewed towards proactivity. Proactiveness is also used in this study as a measure of employee intrapreneurial behaviour. It is operationalised as 1) thinking in terms of future, 2) taking initiatives and 3) being active not passive in the business environments.

\section{Social Cognitive Theory}

Social cognitive theory is a learning theory based on the idea that people learn by observing others. These learned behaviour are central to one's personality even though social psychologist argues that the environment one grows up in contributes to behaviour the individual person is just as important. Bandura (2001) also argues that behaviour is influenced by the interaction of the following three determinants: personal, which is related to whether the individual has a sense of self-efficacy and how high or low is this self-efficacy towards behaviour (selfefficacy); behavioural, which is related to the response an individual receives after they perform a behaviour (outcome expectation) and environmental, related to aspect of the environment or a particular setting that influence the individual's ability to successfully complete a behaviour. This theory guides this study in understanding how the individual's self-efficacy and outcome expectation influence employees towards an intrapreneurial behaviour. The argument is, in as much as the environment matters when an individual's behaviour is mentioned, the individual's own positioning is of prime concern.

Self-efficacy describes an individual's belief in his or her ability and capacity to successfully complete a given task. According to Bandura (1986), self-efficacy does not necessarily reflect the skills one has, but the judgment of what one can do with whatever skills one possesses. Self-efficacy affects the cognitive functioning of an individual, and may predict, mediate and influence behaviour towards work (Wood and Bandura 1989, Pajares and Graham 1999, Usher and Pajares 2006). Self-efficacy could be seen as a process of psychological change operating through the alteration of individuals' expectations (Bandura 1977, 1986, 1997). Efficacy beliefs are said to determine subsequent behaviour, both in terms of the initiation and the persistence of behaviour (Bandura 1982) and that people take action when they hold high efficacy beliefs that make the effort seem worthwhile.

Self-efficacy may emanates from a number of sources; an individual's past experience of accomplished performance, vicarious experience obtained from mentors, role models -learned by observing them or reading about them, verbal persuasion from encouragement and exhortation from people friends, family members and emotional arousal which is obtained from a stressful or a rise of a necessity (Bandura 1977, 1982, Muretta 2005). A critical look at the sources of self-efficacy leads itself into either a 'pull' or a 'push' factor of entrepreneurship. This explains why self-efficacy is not a static trait (Hollenbeck and Hall 2004) as exposure and experience acquired through learning from mentors, role-models, as well as an individual's passion over a new business idea could naturally push an individual to become efficacious. Gist and Mitchell (1992) also argue 
that self-efficacy is task-specific. It is a conditional state that is proximal to behaviour.

Pinchot (1999) suggests a set of skills, abilities and behaviours necessary to be developed among the employees for promotion of organisational intrapreneurism. Out of the ten skills ${ }^{1}$ proposed by Pinchot in assisting organisations to be supportive for intrapreneurism, self-efficacy was identified as a robust factor affecting behaviour. However, self-efficacy has been researched extensively in social science disciplines but more recently in management and entrepreneurship research (Barakat et al. 2014). Thus, research on self-efficacy in management and entrepreneurship has not been extensively done in literature. For example Yusuf (2011) conducted a study in Malaysia using 300 UKM undergraduate students who responded to the research questionnaires which include four constructs, namely, the self-efficacy construct (3 sub-scales), achievement motivation construct ( 3 sub-scales), and self-learning strategies construct (6 sub-scales). The Path Analysis revealed a direct effect of self-efficacy on participants' academic accomplishment. Additionally, the analysis of direct and indirect results indicated the meditational role of self-efficacy on achievement motivation and learning strategies. Similar finding was established through the use of a step by step regression by Motlagh et al. (2011) that self-efficacy could have an effect on Iran high school students' academic achievements. Artino (2012) in his study on academic self-efficacy: from educational theory to instructional practice revealed that self-efficacy was the strongest single predictors of college students' academic achievement and performance. These findings could be due to the nature of academic institutions where an individual would have to put up his/her best against all odds to be able to excel. However, these studies did not consider self-efficacy and intrapreneurial behaviour from the angle of employees in small firms as the academic setting and the small business setting are not same.

Other empirical studies on self-efficacy and entrepreneurial intention and orientation such as Boyd and Vozikis (1994), Mohd et al. (2015), have found positive relationships between the two concepts. These results could be attributed to the nature of entrepreneurship, where someone with a daring attitude who believes in his/her ability is what is needed to start and complete an entrepreneurial venture. However, in the Africa context in particular Ghana, where people may not be daring, may be having phobias to change and always sceptical about questioning the status quo coupled with lack of resources; will self-efficacy increase entrepreneurial practices? However, this current study focus on employee self-efficacy and intrapreneurial behaviour not entrepreneurial behaviour, therefore different findings may be obtained. Gist and Mitchell (1992) stress that selfefficacy is a task-specific belief and that self-efficacy measurement should therefore be tailored to the specific domain under study.

\footnotetext{
${ }^{1}$ Pinchot (1999) suggests ten steps to intrapreneurism in firms; 1) social knowledge to make innovations significant, 2) prior intrapreneurial or entrepreneurial understanding, 3) inventiveness, 4) to identify prospects that others could not identify, 5) to interact with other organisational experts and customers, 6) to correspond effectively across the technical boundaries, 7) self-efficacy in initiating or leading the organisational change processes, 8) risk orientation, 9) forbearance against uncertainty and ambiguity and 10) high need for achievement, understanding the organisational power and politics.
} 
Cetin (2011) also conducted a study to discover the role of self-efficacy and locus of control on the process of intrapreneurship among 211 employees in the information sector in Turkey. Findings reveal that employees with high selfefficacy succeed on intrapreneurial processes and activities particularly in innovativeness. Comparing entrepreneurship and intrapreneurship, employees with high self-efficacy could behave intrapreneurial where the onus of resources provision for any intrapreneurial action lies on the owner manager. In that context what is required, of the employees is the "can do spirit" while with entrepreneurship high self-efficacy alone may not suffice for entrepreneurial action. The sufficient condition of marshalling the crucial resources before that entrepreneurial action may also need to be considered. Context is of essence in research since each context exhibit different social, legal, political, economic policies. Therefore, the Turkish context may be different from the Ghanaian context which is the focus of this study. As a result, findings may differ. Moreover, Cetin (2011) study did not consider employees in the SME sector. Thus, studies on employee self-efficacy and intrapreneurial behaviour in SME are almost missing in literature.

Outcome expectation on the other hand, is the anticipation that a given behaviour will or will not lead to a given outcome. It is the consequences of one's actions (Bandura 1986). Most intentional human behaviour is regulated by forethought (Bandura 1982). Borrowing from Vroom expectancy theory, individuals would always weigh various options to take the behaviour that brings maximum and favourable returns. Research on outcome expectations has found that they influence work-related outcomes, such as knowledge sharing (Hsu et al. 2007) and innovative work behaviour (Yuan and Woodman 2010). Most of the studies on behaviour, used self-efficacy beliefs, however, rarely touched on outcome expectation. This gap is the same line of criticism for Bandura (1997) work, where he was accused of doing more work on efficacy beliefs as oppose outcome expectation. Very few studies including Dorner (2012) made use of innovative self-efficacy and outcome expectation and their effect on innovative work behaviour.

The cross-sectional results from a survey of 350 employees and their direct supervisors in a Swiss insurance company show that innovative work behaviour positively influences task performance. The results from Structural Equation Modeling (SEM) further show that innovative self-efficacy is a strong predictor for innovative work behaviour. Moreover, the findings support that innovative self-efficacy beliefs determine outcome expectations. Thus, positive outcome expectations could represent another source of the motivation. However, the results also show that outcome expectations do not contribute to the prediction of innovative work behaviour. Recent research on the link between outcome expectations and innovative work behaviour has provided empirical support for expected positive performance outcomes being positively related to innovative work behaviour (Yuan and Woodman 2010). Accordingly, it is hypothesized that:

$H_{1}$ : Self-efficacy expectations positively affect intrapreneurial behaviour.

$\mathrm{H}_{2}$ : Outcome expectations positively influence intrapreneurial behaviour. 
However, these studies did not consider employees in SME. They also did not make use of the broader term intrapreneurship. They used a function of intrapreneurship which is innovation. This current study examines the variance of intrapreneurial behaviour based on employees' efficacy beliefs and outcome expectation among employees in SMEs.

\section{Self-efficacy Expectations and Outcome Expectation}

Although both self-efficacy expectations and outcome expectations influences behaviour, one would wonder which one triggers the other to causing a behaviour. Social cognitive theory assumes that the type of outcomes people anticipate depend largely on their judgment of how well they can perform (Bandura 1986). More precisely, people see outcomes as contingent on the adequacy of their performance and they rely on their efficacy beliefs/expectations when judging their anticipated performance. The argument here is that an individual's efficacious behaviour has an important impact on the results of one's actions. Thus, efficacy beliefs influence the anticipated outcomes. For example, employees who judge themselves inefficacious in identifying new ideas and trying to push them through to a product will not become intrapreneurs. This, in turn, results in nonintrapreneurship behaviour. This argument is supported by one of Vroom (1964) theory; expectancy; which he define as a subjective probability of an action or effort leading to an outcome. Thus, it measures the perceived correlation between an action and an outcome. A study by Compeau et al. (1999) and Hsu et al. (2007) among students, found that computer self-efficacy beliefs affect outcome expectations related to the use of computers. These researches did not study the behaviour of employees within an establishment who sometimes could go an extra mile based on a promised bonus.

Contrary, from the generic assumption of Vroom (1964) expectancy theory, people select behaviour over others, based on what they expect the result/outcome of that behaviour to be. This indicates that at some point, favourable outcome expectations could make people to become efficacious. Based on the above discussions, a conceptual framework was developed to depict this relational flow (See Figure 1). The predictor variables are self-efficacy (looking at workers efficacy expectation and their outcome expectation) and organisational resources (mediator) while the criterion variable is intrapreneurial behaviour with innovativeness and proactiveness as its indicators. The hypothesized relationships are described next.

Figure 1. Conceptual Framework Depicting the Relational Flow between Selfefficacy, Firm Resources and Intrapreneurial Behaviour with their Coefficient

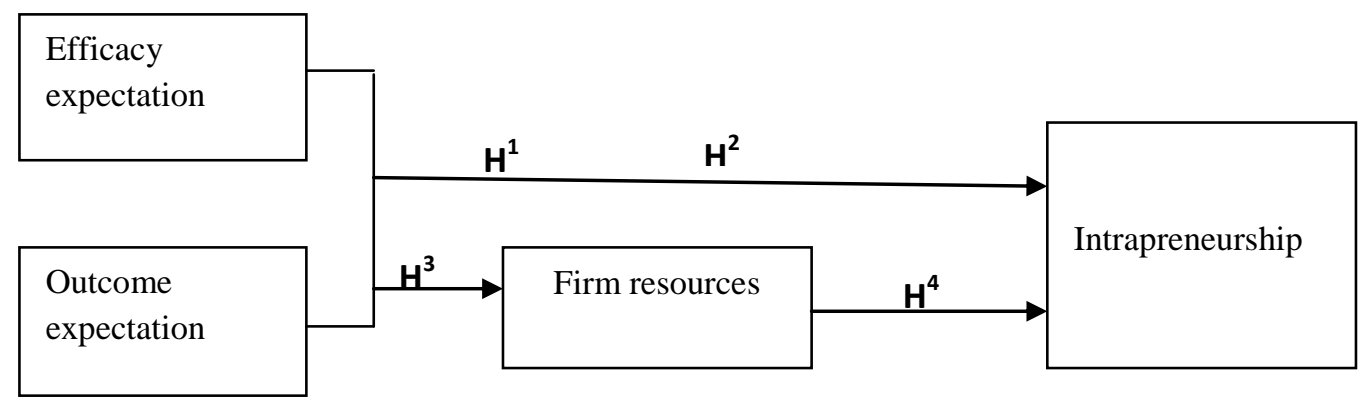




\section{Firm Resources and Employee Intrapreneurial Behaviour}

According to Deloitte Global Report (2015), employees need resources (time, physical, financial, human) in order to come up with innovations. The " $20 \%$ Rule" principle applied by Google in which employees are allowed to spend one day per week on a project that is unrelated to their work is a way of enhancing the intrapreneurial drive in workers. However, it is an observed fact that SMEs unlike large firms face typical resource constraints that often inhibit their intrapreneurial pursuit. Some studies are of the view that inadequate and in some cases lack of resources in SMEs limits their ability to behave intrapreneurial particularly in the area of innovation. Others are of the view that it the resource constraint cannot inhibit their intrapreneurial behaviour. A study carried out by De Massis et al. (2017) among the German Mittelstand firms using a model identifying and integrating six salient traits of firms that allow them to efficiently orchestrate their resources to innovate and outcompete their competitors in the global market, enabling those firms to overcome their resource-related weaknesses and turn them into strengths. It was reveal that resource unavailability could not hinder German Mittelstand firms from behaving innovatively.

A study by Hewitt-Dundas (2006) on resource and capability constraints to innovation in small and large plants revealed that the unavailability of resources may constrain intrapreneurship characterised by innovation on the part of small firms. Urbano et al. (2013) in their study on the influence of resources and capabilities on the probability of becoming an intrapreneur found that companies' resources and capabilities are a key factor in the development of intrapreneurship.

In as much as these previous studies informed this present study, they did not examine the mediating role of firm resources availability on the employee intrapreneurial behaviour. Thus, literature is not informing whether the presence of firm resources could make employees go an extra mile to behave intrapreneurial. Therefore, this current study examined the mediating effect of firm resources on the relationship between antecedents of employee intrapreneurial behaviour and intrapreneurial behaviour. It is therefore hypothesised that:

$H_{4}$ : Firm resource has a mediating effect on employee self-efficacy and intrapreneurial behaviour.

$H_{5}$ : Firm resource has a mediating effect on employee self-efficacy and intrapreneurial behaviour.

\section{Methodology}

The study is based on an explanatory design where the used of descriptive is inevitable (Saunders et al. 2012). A total list of 53 fruit juice processing enterprises of Ghana was obtained from the Fruit Processors and Marketing Association of Ghana (FPMAG). This is a National association that coordinates the affairs of SMEs in fruit processing. This total number of 53 comprised of SMEs into dry fruits juice processing, SMEs into fresh fruit juice processing 
and large firms into fresh fruits juice processing. Thirty-four (34) out of the 53 fell under the SMEs in fresh fruit juice processing which was the interest of this study. This list has been obtained from Fruit Processors and Marketers Association of Ghana (FPMAG).

A total of 1870 non managerial employees in the 34 SMEs spread within the three regions are included in the sampling frame. This figure is derived by summing the lowest (5) and the highest (50) number of employees likely to be engaged by these SMEs. This figure was then multiplied by the total number of SMEs (34) obtained from FPMAG. That is $(34 * 55)=1870$ employees. This method was employed because it was not practical to obtain the total number of employees in each SMEs considered in this study. From the total of 1870, a sample of 282 units has been drawn with a confidence level of $95 \%$ using the formula derived by Kothari (2014). The sample size in any research work is very crucial because the size of the sample dictates the level of sampling error which can limit the extent of generalisation as well as conclusions about the population.

$$
\mathrm{n}=\frac{\mathrm{Z}^{2} \cdot p \cdot q \cdot \mathrm{N}}{\mathrm{e}^{2}(\mathrm{~N}-1)+\mathrm{z}^{2} \cdot \mathrm{p} \cdot \mathrm{q}}
$$

Which is valid where $\mathrm{n}$ is the sample size, $\mathrm{Z}$ obtained from normal distribution table (1.96), under a confidence level, 95\%, e is the desired level of precision 5\%, $\mathrm{p}$ is the estimated proportion of an attribute that is present in the population (0.5), and $\mathrm{q}$ is $1-\mathrm{p}(0.5) . \mathrm{N}$ is the total sample size. The sample size of 282 has been increased to 290 after proportional distribution of the sample size into each region. This is because all decimals were converted to whole number thereby increasing the sample size.

To collect data for this study, a survey was conducted involving 290 employees from fresh fruit juice processing SMEs in Ghana. Using a simple random technique, 234 responses were secured, which made an 81 percent response rate. This is adequate given that a response rate of at least 50 percent is suitable for use (Mugenda and Mugenda 2010). Employees were chosen because they are the focus of intrapreneurship studies (Stevenson and Jarillo 1990). Three regions (Greater Accra, Eastern and Central) of Ghana were chosen for the study. These regions were chosen because they have a large concentration of SMEs who operate in juice processing industry. Probability sampling was employed in the context of stratified samples to select the respondents. Data was assessed for reliability at Cronbach Alpha Coefficient of 0.925. This is above the ideal Cronbach Alpha of 0.7 (Rogue et al. 2014, Hair et al. 2014). However, some of the individual variables produced internal coefficients below 0.7 , but generated acceptable internal coefficients of 0.5 . Content and face validity were ensured by giving the research tool to expert in entrepreneurship to assess while construct and discriminant validity was ensured using exploratory and confirmatory factor analysis. 
The survey instruments contained measurement items derived from previous studies. Self-efficacy items were adapted Bandura (1986) and other related studies (Cetin 2011). Items were anchored on a 5-point Likert scale whereby $1=$ very low extent to $5=$ very high extent. The indicators of intrapreneurial behaviour were measured by item adapted from Antoncic and Hisrich (2003) and anchored on a five-point Likert scale ranging from $1=$ high in disagreement to $5=$ high in agreement. Firm resource was developed and measured on a five-point scale ranging from $1=$ a very little extent to $5=$ very high extent.

Items used in measuring organisational resources produced two components; resource for production such as (water, raw material, electricity, tools and equipment for production) and intrapreneurial resources such as (the presence of an intrapreneurial inclined workers and or owner manager, in-house knowledge on intrapreneurship acquired through trainings and workshop, intrapreneurial networks, money) Money which is perceived to be a factor of production, loaded under intrapreneurial resources after six iterations. This suggests that money is an indispensable resource for intrapreneurial activities.

Questionnaires were administered in person and the returned questionnaires were checked, numbered and the items coded and processed using SPSS 22. Outliers and missing values were checked and assumptions for normality, homogeneity, linearity and collinearity were met. Exploratory factor analysis (EFA) and confirmatory factor analysis (CFA) were conducted to check the validity and to reduce items used in measuring the study constructs. A total of 30 items were used in conducting exploratory factor analysis. After six (6) iterations, six (6) components were produced with 22 items retained. The items that were isolated either cross loaded or did not produce the threshold value of 0.4 (Hair et al., 2014). Each component culminated into a study construct. The six components produced a total variance of $65.58 \%$, KMO 0.847 , Bartlett's test of sphericity $\left(x^{2}=\right.$ 2382.198, df $253 \mathrm{p}<0.001)$.

\section{Research Findings}

Sample characteristics were analysed using frequency distributions (Table 3). Analysis shows gender groups are fairly represented with 59.4\% males. The modal age group is $25-31$ years $(38.5 \%)$ with $62.4 \%$ in the range $18-31$ years. With respect to level of education, $37.8 \%$ of respondents had attended senior high school. Table 2 shows the demographic description of the study participant.

Output from sampled characteristics reflect the characteristics of the study context where the population is youthful, male mostly accepted in the industries compared to their female counterparts and with a moderately high rate of literacy. In the case of the measures of all study constructs as shown in Table 3, all items used seemed important for the measurement of the study constructs. This is because they have quite large mean values, indicating their contribution to each of the constructs. 
Table 2. Demographic Characteristics

\begin{tabular}{|l|c|}
\hline Demographics & Percentages \\
\hline Gender & \\
\hline Male & 59.4 \\
\hline Female & 40.6 \\
\hline Age & 23.9 \\
\hline $18-24$ & 38.5 \\
\hline $25-31$ & 19.2 \\
\hline $32-38$ & 18.4 \\
\hline 39 and above & \\
\hline Level of Education & 10.3 \\
\hline Basic & 19.7 \\
\hline Junior high school & 30.3 \\
\hline Senior high school & 24.8 \\
\hline Diploma & 11.5 \\
\hline Bachelor & 1.7 \\
\hline Postgraduate & 1.7 \\
\hline Others & \\
\hline
\end{tabular}

The reliability analyses as shown in Table 4 indicate that the 6 factors undoubtedly resemble the concepts. Although it may be argued that the more the number of items for the variable the greater the reliability, it is observed that the reliability weight for the individual item matters most and not just the quantity of the items. For instance, a construct with only three items produce a reliability scale of 0.884 which is higher than a construct with four items as shown in Table 4 . In addition, all the variables produced an above average reliability coefficients of 0.7 . These reliability figures are above the threshold recommended by Hair et al (2014) to be the acceptable reliability for a study construct. This indicates that the study data are reliable.

Table 3. Mean Scores on Study Variables

\begin{tabular}{|l|c|c|c|}
\hline & $\mathbf{N}$ & Mean & Std. Dev \\
\hline Ability to encourage to try out new Things & 234 & 3.94 & 0.974 \\
\hline Confident in my ability to solve problems creatively & 234 & 4.00 & 0.816 \\
\hline Growth of the firm & 234 & 4.07 & 0.717 \\
\hline Increase in competitiveness & 234 & 4.08 & 0.725 \\
\hline New ways of carrying out activities & 234 & 3.98 & 0.821 \\
\hline Constantly modifying production processes & 234 & 3.95 & 0.754 \\
\hline Constantly developing new product lines & 234 & 3.96 & 0.883 \\
\hline Constantly improving upon old products and raising the quality of new ones & 234 & 4.21 & 0.718 \\
\hline Finding ways of overcoming obstacles ahead of time & 234 & 4.24 & 0.724 \\
\hline Being proactive means being a risk taker & 234 & 4.17 & 0.701 \\
\hline Being proactive means being able to anticipate and plan events ahead of time & 234 & 4.13 & 0.738 \\
\hline Being proactive means being 'up and doing' & 234 & 4.23 & 0.698 \\
\hline Presence of intrapreneurial inclined workers & 234 & 4.04 & 0.907 \\
\hline Intrapreneurial knowledge acquired through training and workshops & 234 & 3.91 & 1.034 \\
\hline Intrapreneurial networking & 234 & 3.86 & 0.962 \\
\hline Financial resources to implement ideas & 234 & 3.89 & 0.992 \\
\hline Office space for working out new ideas & 234 & 4.03 & 0.928 \\
\hline Equipment for production & 234 & 4.28 & 0.732 \\
\hline Water for production & 234 & 4.38 & 0.679 \\
\hline Raw materials for production & 234 & 4.41 & 0.694 \\
\hline Electricity for production & 234 & 4.37 & 0.669 \\
\hline
\end{tabular}


Table 4. Reliability Test

\begin{tabular}{|l|l|l|l|l|c|}
\hline \multicolumn{2}{|l|}{$\begin{array}{l}\text { Construct and their reliability } \\
\text { Before EFA (items) }\end{array}$} & \multicolumn{2}{|c|}{ Construct after EFA } & \multicolumn{2}{|c|}{$\begin{array}{l}\text { Construct and their } \\
\text { reliability after CFA }\end{array}$} \\
\hline Efficacy Expectation (5) & 0.796 & $\begin{array}{l}\text { Efficacy } \\
\text { beliefs (2) }\end{array}$ & 0.623 & $\begin{array}{l}\text { Efficacy } \\
\text { Expectation (2) }\end{array}$ & 0.623 \\
\hline Outcome Expectation (5) & 0.792 & $\begin{array}{l}\text { Outcome } \\
\text { Expectation(2) }\end{array}$ & 0.660 & $\begin{array}{l}\text { Outcome } \\
\text { Expectation (2) }\end{array}$ & 0.660 \\
\hline Innovativeness (6) & 0.874 & Innovativeness (4) & 0.825 & Innovativeness (4) & 0.825 \\
\hline Proactiveness (5) & 0.714 & Proactiveness (4) & 0.799 & Proactiveness (4) & 0.799 \\
\hline $\begin{array}{l}\text { Resources for production } \\
\text { (5) }\end{array}$ & 0.817 & $\begin{array}{l}\text { Resources for } \\
\text { production (5) }\end{array}$ & 0.817 & $\begin{array}{l}\text { Resources for } \\
\text { production (4) }\end{array}$ & 0.803 \\
\hline $\begin{array}{l}\text { Intrapreneurial resources } \\
\text { (4) }\end{array}$ & 0.884 & $\begin{array}{l}\text { Intrapreneurial } \\
\text { resources (4) }\end{array}$ & 0.884 & $\begin{array}{l}\text { Intrapreneurial } \\
\text { resources (3) }\end{array}$ & 0.884 \\
\hline $\begin{array}{l}\text { Composite Reliability } \\
\text { (30) }\end{array}$ & $\mathbf{0 . 9 2 5}$ & $\begin{array}{l}\text { Composite } \\
\text { Reliability (19) }\end{array}$ & $\mathbf{0 . 8 5 1}$ & $\begin{array}{l}\text { Composite } \\
\text { Reliability (18) }\end{array}$ & $\mathbf{0 . 8 4 5}$ \\
\hline
\end{tabular}

\section{Confirmatory Factor Analysis}

Table 5 presents the results of the confirmatory factor analysis (CFA) for the measurement models of all five constructs of employee efficacy beliefs, outcome expectation, firm resources availability, innovativeness and proactiveness. The analyses are evaluated in terms of the CMIN, RMSEA, TLI and the CFI measures of fit; the statistical significance of the estimated coefficients, squared multiple correlation coefficient, composite reliability and average variance extracted are significantly associated with their observed variables because all the estimation parameters of those variables are acceptable, which shows the signs are positive. The measures of fit for the TLI and the CFI are evaluated in the context of suggested minimum threshold values of 0.9 (Arbuckle 2012). The statistical significance of coefficients is evaluated in terms of the results of a hypothesis test with the null hypothesis that the true coefficient is zero using a significance level of 5\%. The SMCC is evaluated in terms of the minimum value of 0.3 (Jöreskog and Sorrbom 1982). Construct reliability (CR) should have the lower threshold, which is equal to 0.7 and the variance extracted (VE) should have the lower threshold, which is equal to 0.5 . The squared multiple correlation coefficient (SMCC) should be at least 0.3 (Jöreskog and Sörbom 1982, Hair et al. 2014). The root mean square error of approximation (RMSEA) index constitutes a parsimony measure that depicts the discrepancy between the observed and estimated covariance matrices per degree of freedom. RMSEA values below 0.08 are considered good fit (Browne and Cudeck 1993).

Table 5. Indices of Confirmatory Factor Analysis

\begin{tabular}{|l|c|c|}
\hline Indices & Measure of Fit & Remarks \\
\hline Chi-Square/Degree of Freedom CMIN/DF & 1.626 & Very fit \\
\hline $\begin{array}{l}\text { Root Mean Square Error of Approximation; } \\
\text { RMSEA }\end{array}$ & 0.052 & Fit \\
\hline Tucker and Lewis Index;TLI & 0.937 & Very fit \\
\hline Comparative Fit Index;CFI & 0.948 & Very fit \\
\hline Goodness of Fit Index;GFI & 0.901 & Fit \\
\hline Incremental Index of Fit;IFI & 0.949 & Very fit \\
\hline PCLOSE & 0.380 & Closely fit \\
\hline
\end{tabular}


A look at Table 6 shows that all the model indices for this study were within the ideal model indices threshold. Hence, the measurement model data closely fit the model proposed for this study.

As shown in Table 6, the probability for variables in the prediction of each item are significantly different from zero at a 0.001 (two-tailed) indicating that for the model to predict the dependent variable for any value of independent variable is valid.

\section{Results of the Structural Equation Model Analysis for the Conceptual Model}

In order to test the proposed relationships between self-efficacy beliefs, outcome expectations, and intrapreneurial behaviour, structural equation modeling was applied. The first was to test the straight line effect between employee selfefficacy beliefs and outcome expectations on intrapreneurial behaviour.

From Table 7, it can be mentioned that consistent with hypothesis 1, employee self-efficacy beliefs has a statistically significant positive effect on intrapreneurial behaviour $(\beta=0.98, \mathrm{p}<.001)$ while hypothesis 2 has also been confirm based on the findings that outcome expectations has significant positive effect on intrapreneurial behaviour $(\beta=0.19, \mathrm{p}<0.005)$. However, hypothesis 2 is supported with a weak standard coefficient, which provides theoretical evidence to support employee intrapreneurial behaviour. Nevertheless, findings support hypotheses 1 and 2.

To test for mediation, the procedures of Mathieu and Taylor (2006) were followed, which test: (1) whether there is a significant relationship between independent and dependent variables; (2) whether the relationship between independent and mediator variables is significant; (3) whether there is a significant relationship between mediator and dependent variables; and (4) whether the relationship between independent and dependent variables becomes less or nonsignificant when the influence of the mediator is controlled. The results of the main effects show that Mathieu and Taylor's (2006) preconditions (1) and (2) were met for both self-efficacy beliefs and outcome expectation which had produced an insignificant direct effect. 
Table 6. Confirmatory Factor Analysis Outputs

\begin{tabular}{|c|c|c|c|c|c|c|c|c|c|}
\hline & & & $\begin{array}{l}\text { Unstandard } \\
\text { Estimate }\end{array}$ & S.E. & C.R. & $\mathbf{P}$ & $\begin{array}{c}\text { Standardized } \\
\text { Regression } \\
\text { Weight Estimate }\end{array}$ & $\begin{array}{c}\text { Squared Multiple } \\
\text { Correlation } \\
\text { Coefficients }\end{array}$ & $\begin{array}{l}\text { Average } \\
\text { Variance } \\
\text { Extracted }\end{array}$ \\
\hline EBLS1 & <--- & Efficacy & 1.000 & & & & 0.764 & 0.584 & \\
\hline EBLS2 & $\begin{array}{l}<-- \\
\end{array}$ & Efficacy & 0.658 & .081 & 8.142 & $* * *$ & 0.601 & 0.361 & 0.41 \\
\hline OEXP1 & $\begin{array}{l}<--- \\
\end{array}$ & Expectation & 1.000 & & & & 0.819 & 0.671 & \\
\hline OEXP2 & $\begin{array}{l}<-- \\
\end{array}$ & Expectation & 0.743 & .264 & 2.817 & .005 & 0.601 & 0.362 & 0.25 \\
\hline RA1 & $<---$ & Resprod & 1.000 & & & & 0.571 & 0.326 & \\
\hline RA2 & $<---$ & Resprod & 1.102 & .129 & 8.539 & $* * *$ & 0.798 & 0.637 & \\
\hline RA3 & $<--$ & Resprod & 1.031 & .122 & 8.430 & $* * *$ & 0.806 & 0.649 & \\
\hline RA4 & <--- & Resprod & 0.940 & .117 & 8.055 & $* * *$ & 0.744 & 0.554 & \\
\hline RA5 & $<---$ & Resprod & 0.730 & .107 & 6.843 & $* * *$ & 0.566 & 0.320 & 0.29 \\
\hline INTPRS1 & $<--$ & Hrintr & 1.000 & & & & 0.702 & 0.493 & \\
\hline INTPRS2 & $\begin{array}{l}<-- \\
\end{array}$ & Hrintr & 1.384 & .112 & 12.32 & $* * *$ & 0.849 & 0.720 & \\
\hline INTPRS3 & $\begin{array}{l}<-- \\
\end{array}$ & Hrintr & 1.353 & .108 & 12.54 & $* * *$ & 0.892 & 0.795 & \\
\hline INTPRS4 & $\begin{array}{l}<-- \\
\end{array}$ & Hrintr & 1.256 & .110 & 11.41 & $* * *$ & 0.803 & 0.645 & 0.31 \\
\hline INN1 & $<---$ & Innovation & 1.000 & & & & 0.825 & 0.681 & \\
\hline INN2 & $<---$ & Innovation & 0.968 & .064 & 15.22 & $* * *$ & 0.869 & 0.755 & \\
\hline INN3 & $<--$ & Innovation & 0.963 & .080 & 11.99 & $* * *$ & 0.739 & 0.546 & \\
\hline INN4 & $<--$ & Innovation & 0.598 & .069 & 8.680 & $* * *$ & 0.564 & 0.318 & 0.26 \\
\hline PRO1 & <--- & Proactive & 1.000 & & & & 0.656 & 0.430 & \\
\hline PRO2 & <--- & Proactive & 1.137 & .121 & 9.433 & $* * *$ & 0.770 & 0.593 & \\
\hline PRO3 & $<---$ & Proactive & 1.262 & .135 & 9.364 & $* * *$ & 0.812 & 0.660 & \\
\hline PRO4 & $<---$ & Proactive & 0.878 & .116 & 7.543 & $* * *$ & 0.597 & 0.357 & 0.25 \\
\hline
\end{tabular}

S.E $=$ Standard Error; C.R. $=$ Critical Ratio $; P=$ Probability. 
Table 7. Regression Weights of the Employee Self-Efficacy, Outcome Expectation and Intrapreneurial Behaviour. Direct Effect

\begin{tabular}{|c|c|c|c|c|c|c|c|c|c|}
\hline & & & $\begin{array}{c}\text { USTD } \\
\text { Estimate }\end{array}$ & S.E. & C.R. & $\mathrm{P}$ & $\begin{array}{c}\text { STD } \\
\text { Estimate }\end{array}$ & SMCC & AVE \\
\hline Intrapreneurship & $\begin{array}{l}<-- \\
\end{array}$ & Outcome expectation & 0.085 & 0.039 & 2.172 & 0.030 & 0.190 & 0.662 & \\
\hline Intrapreneurship & $<---$ & Efficacy & 0.379 & 0.072 & 5.255 & $* * *$ & 0.982 & 0.739 & \\
\hline EBLS1 & $<--$ & Efficacy & 1.000 & & & & 0.687 & 0.539 & \\
\hline EBLS2 & $<---$ & Efficacy & 0.695 & 0.088 & 7.927 & *** & 0.571 & 0.319 & 0.672 \\
\hline OEXP1 & $<---$ & Outcome expectation & 1.000 & & & & 0.806 & 0.134 & \\
\hline OEXP2 & $<---$ & Outcome expectation & 0.766 & 0.303 & 2.531 & 0.011 & 0.610 & 0.138 & 0.3445 \\
\hline PRO4 & $<--$ & intrapreneurship & 1.000 & & & & 0.371 & 0.372 & \\
\hline PRO3 & $<--$ & Intrapreneurship & 1.042 & 0.196 & 5.320 & $* * *$ & 0.366 & 0.649 & \\
\hline INN4 & $<---$ & Intrapreneurship & 1.563 & 0.316 & 4.950 & $* * *$ & 0.565 & 0.326 & \\
\hline INN3 & $<--$ & Intrapreneurship & 2.489 & 0.464 & 5.370 & $* * *$ & 0.734 & 0.472 & \\
\hline INN2 & $<---$ & Intrapreneurship & 2.481 & 0.447 & 5.554 & $* * *$ & 0.859 & 0.662 & \\
\hline INN1 & $<---$ & intrapreneurship & 2.559 & 0.465 & 5.498 & $* * *$ & 0.814 & 0.739 & \\
\hline
\end{tabular}


Table 8. Regression Weights of Employee Self-Efficacy, Outcome Expectation, Firm Resources and Intrapreneurial Behaviour Indirect Effect

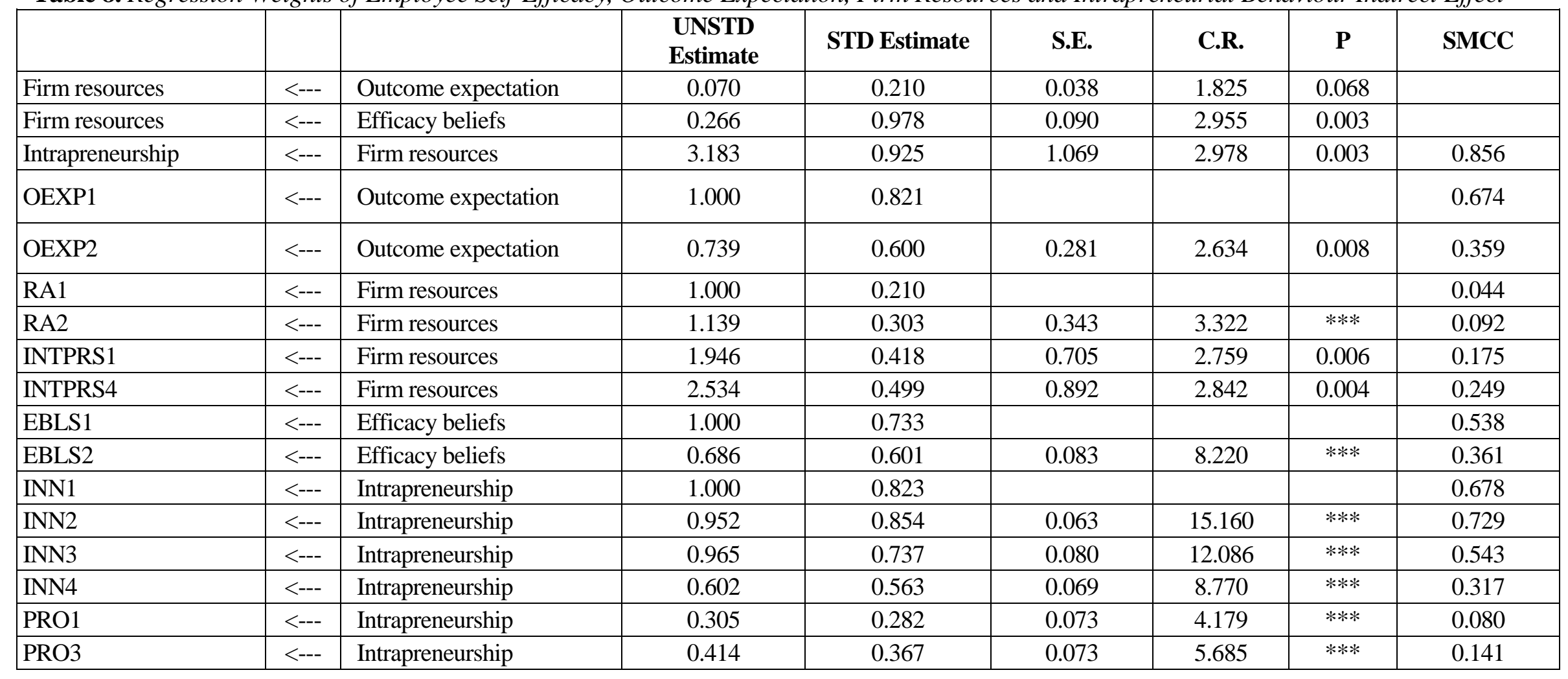


Figure 2. Structural Equation Modelling Output

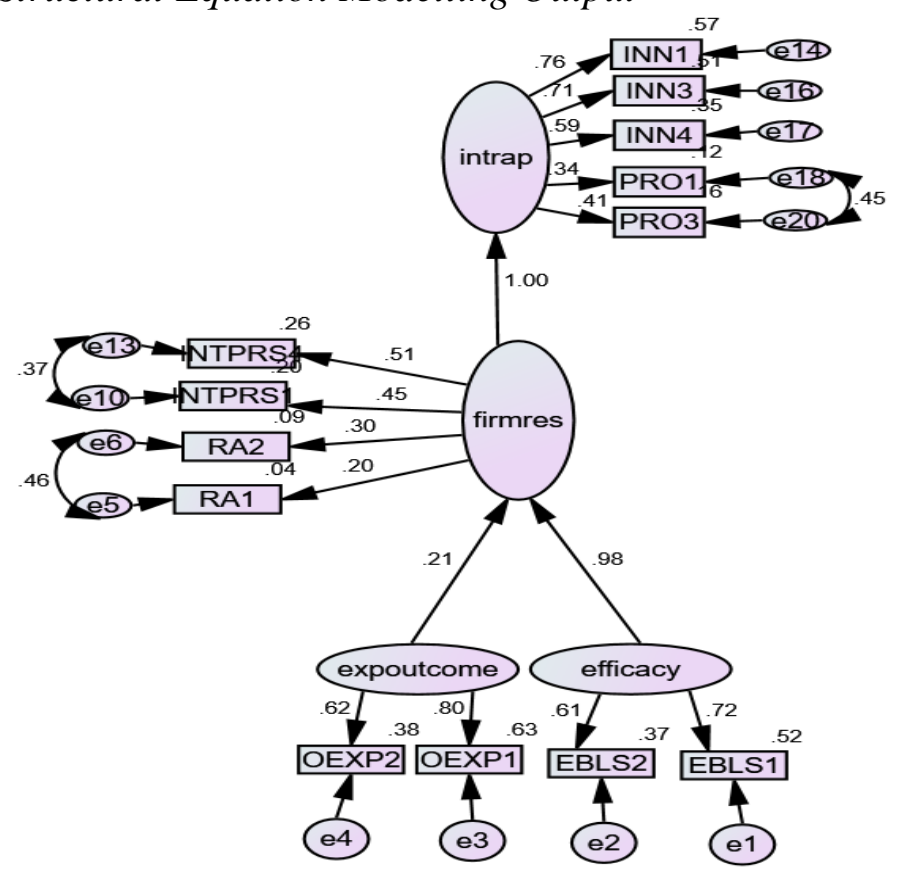

As seen in Table 8 and Figure 2, when the mediator was introduced into the model, the precondition (3) for mediation was also met. Thus, there is a statistically significant positive relationship between firm resources and intrapreneurial behaviour $(\beta=1.000, \mathrm{p}<0.005)$, supporting hypothesis 3 . In addition, precondition 4 for Mathieu and Taylor (2006) was also met such that outcome expectations became insignificant when the mediator was introduced. Employee self-efficacy belief on the other hand, was still statistically significant, but its significant power diminished from $\mathrm{P}<0.001$ to $\mathrm{P}<0.005$. This indicates that the explanatory powers of both outcome and efficacy expectation is shared by the presence of firm resource. Therefore, it could be concluded that the model is recursive. Consideration of the significance of the paths in the structural model indicates that of the 17 estimated coefficients, 16 measures associated with the construct are statistically significant.

This study investigated two kinds of expectations as antecedents of intrapreneurship behaviour. Two kinds of expectations regarding behaviour from Social Cognitive Theory was applied (Bandura 1977, 1986). Expectations in terms of self-efficacy and outcome are important determinants of behaviour (Bandura 1997). In addition, initiating and sustaining an intrapreneurial behaviour among employees is influenced by both characteristics of the firm itself and by characteristics of the individuals involved.

The final model as indicated by Figure 2 shows the regression weight accounting for the relationship between the efficacy beliefs, outcome expectation as mediated by firm resources availability. 


\section{Discussion}

The exploratory analyses conducted show that employees' in SMEs may have a high level of self-efficacy beliefs/expectation and outcome expectation, in particular those in the fresh fruit juice processing industry. This finding suggests that employees in SMEs believe in their ability to start and successfully complete any given task, and this could lead to a higher intrapreneurial behaviour. This finding could be explained from the traditional perspective of how the Ghanaian child is brought up to become efficacious through poetry, traditional songs, drama, poetry and encouragement from the society. That is, the social environment educates the Ghanaian child in particular the male child, to be efficacious growing up.

The empirical investigation shows that employees' self-efficacy beliefs have an effect on intrapreneurial behaviour. This is consistent with the findings by Wakkee et al. (2010), Wood and Bandura (1989) who found that self-efficacy has a positive effect on intrapreneurial behaviour. This finding also supports the concept of self-efficacy from the social cognitive theory which assumes that the more efficacious an individual is, the higher the tendency for him/her to behave in a particular manner in this instance; intrapreneurial. This finding is not also surprising because the act of entrepreneurship irrespective of where it takes place requires an individual with traits such as self-reliance, resilience, high level of confidence, belief in ones abilities to perform, pragmatic, daring and the can do spirit. Hence, the findings that employees' self-efficacy is a key personal characteristic of intrapreneurship behaviour is in order. Outcome expectation was also significant to employees' intrapreneurial behaviour however, on a lower degree. This finding indicates that the end result of any behaviour or action is a contributory factor to performing that behaviour. This is in line with Vroom (1964) expectancy theory which assumes that a favourable outcome an individual expect could trigger an action or behaviour.

Furthermore, findings of this study discovered that between the two expectations, employee efficacy expectation is a stronger predictor of intrapreneurial behaviour than outcome expectation. That is, employees place much priority on their ability to successfully carry out an assigned task rather than considering the outcome of the behaviour. This supports the argument of Choi et al. (2011) that what you can do, and how well it can be done, determines the outcome. In addition, Bandura (1986) asserts that people may only rely on their perceived self-efficacy when deciding which course of action to pursue because their outcome expectations depend largely on the adequacy of their performance (Bandura 1986). Therefore, outcome expectations may not independently contribute to the prediction of intrapreneurial behaviour over and above selfefficacy beliefs. This finding is similar to Dorner (2012) who found self-efficacy beliefs to be a stronger predictor of innovative work behaviour (an indicator of intrapreneurship) with outcome expectation contributing very minimal to innovative work behaviour.

Resources, both tangible and intangible, are the core elements of any firm (Barney 1991). It affects all the activities in a firm resonating their competitive 
advantage and performance. The study examined whether the presence of resources in firms in the presence of self-efficacy beliefs and a favourable outcome expectation could trigger employees intrapreneurial behaviour. Findings indicate an association between self-efficacy beliefs and firm resource availability. In the presence of employees who are efficacious and in the absence of resources, firms cannot achieve their core aim of existence much less to behave intrapreneurial. This finding is congruent to that of Davidson and Honing (2003) who assert that access to resources enhances the individual's ability to detect and act upon discovered opportunities and vice versa. Thus, firm employees' efficacious in the presence of resource availability may boost intrapreneurial actions. However, outcome expectations seem insignificant to firm resource availability. This implies that the outcome of any behaviour does not necessarily depend on the resources but the attitude to rightfully combine these resources to achieve the desired outcome. This agrees with Penrose (1959) argument on firm resources that it is not the quantity or availability of resources that matter but the rightful coordination and combination of the resources available within a firm.

Regarding the mediating role of firm resources availability, findings reveal that firm resources could be a mediator among employee self-efficacy beliefs, outcome expectation and intrapreneurial behaviour. This presupposes that whenever intrapreneurial activities is to increases as a result of employees' efficaciousness, or favourable outcome expectation, firm resources such as equipment, machines, utilities and raw materials that matter for the processing of fruit juice must be available. In addition, intrapreneurial inclined employees who serve as a role model and offer encouragement to fellow employees', increasing in-house knowledge on intrapreneurship through training and workshop must as well be present.

These findings implied that owner-managers and or managers should pay attention to enhancing the self-efficacy beliefs of employees since it could trigger an individual's intrapreneurial behaviour. They could help employees to increase and maintain their efficacy drive by encouraging them to believe in their abilities and always try out something new. They could also give their employees' additional responsibility and duties using a job rotation strategy, delegating to them as well as ensure an effective two way communication in the firm. Most importantly, an environment free from distractors with resources readily available would be ideal in addition to encouraging employees to establish high quality relationships with co-workers so as to learn from one another. These would increase as well as maintain and sustain the self-efficacy beliefs of employees in SMEs. However, managers should be aware that all employees will not necessarily respond in the same way, hence, varied strategies would be required from time to time.

To the employees in SMEs in particular those in fresh fruit juice processing, findings from this study indicate that how well a task is accomplished determines how good the outcome would be. However, how well an action is carried out is a factor of an individual's self-efficacy beliefs. Having a high self-efficacy is adequate to succeed on any task. Therefore, employees should whip up their selfefficacy beliefs through learning, carefully observing and willingness to try hands 
on new and challenging assignments in and outside their firm. This would increase their efficacy towards handling any assign task. This study asserts that the labour world is gradually shifting from the era of what do you know to what can you do? Thus the belief in one's ability, capability and confidence to efficiently perform a task is relevant in the modern labour market, and this is true in the Ghanaian context as well. Employees must therefore continually hold high their self-efficacy in whatever they are assigned to do. This can have a positive spill-over effect in all aspects of their lives.

The findings also provides an insight into policy making thus, programmes and policy strategies intended to promote intrapreneurship characterised by innovativeness and proactiveness in SMEs must take into account both organisational and individual factors. In line with organisational factors, assisting SMEs with the needed resources (raw materials, machinery and equipment) will suffice. On the individual level, much emphasis should be on targeting strategies to enhance employees' self-efficacy since a highly efficacious employee could be a potential intrapreneur. The National Board for Small Scale Industry (NBSSI) and other relevant stakeholders could also institutionalise clear policy inclined to the training of SMEs on how to develop and/or improve their self-efficacy beliefs.

\section{Contribution of the Study}

Based on the findings of the study, it is clear that all things being equal it could be theorized that whenever self-efficacy beliefs and outcome expectations are perceived positively among employees in SMEs in fresh fruit juice processing, it may not necessarily lead to an intrapreneurial outcome unless there are appropriate and meaningful resources available. Thus, sometimes, the belief in what the employee can do or what they expect as the outcome of their actions may be influenced by other factors such as resources availability. Resource availability may enhance the potency of employees' belief in their abilities leading to intrapreneurial practices within the firms.

With reference to self-efficacy theory, Vroom expectancy theory; findings from this study contribute by establishing that it is not always a positive selfefficacy beliefs that makes individuals to succeed as Bandura (1977, 1997) asserted, neither is it being able to select the best alternative from among the many alternatives (Vroom 1964) that matters, but the presence of meaningful and appropriate resources should be key in assessing an individual's positive selfefficacy towards a behaviour or assessing their level of expectancy towards performing a given task. Furthermore, findings from the study reveal that outcome expectation is not a strong predictor of behaviour. This could partly explain why outcome expectation was not more explicitly mentioned in Bandura (1977) subsequent work as critics of Bandura argue.

In addition, measurement of intrapreneurship has not been conclusive in literature. However, innovativeness and proactiveness have been recorded in literature as robust measures of intrapreneurship. This study confirms that innovativeness and proactiveness are core measures of intrapreneurship; in this 
case for small businesses. In addition, the study contributes to factors which could lead to the emergence of intrapreneurship in SMEs by building a model to serve as a springboard for the development of employee intrapreneurial behaviour in SMEs of Ghana, and in particular those in fresh fruit juice processing. Thus, the research has contributed to the debate about intrapreneurship in SMEs.

\section{Conclusion}

Based on the prime objective of this study, it is concluded that self-efficacy beliefs and outcome expectation explained the variance in employee intrapreneurial behaviour in SMEs. Thus both self-efficacy beliefs and outcome expectation have a positive effect on employee intrapreneurial behaviour. In addition, the explanatory powers of self-efficacy and outcome expectations in predicting intrapreneurial behaviour are shared with the presence of firm resource availability. This shows that the relationship among employee self-efficacy, outcome expectations and intrapreneurial behaviour, flows through the availability of firm resources. Hence, firm resource availability mediates perceived self-efficacy, outcome expectation and employee intrapreneurial behaviour.

\section{Delimitations and Limitations of the Study}

Despite the insight this study sheds, few limitations also exist. For example the effect of self-efficacy beliefs and outcome expectations on employees' intrapreneurial behaviour of SMEs in the fruit juice processing industry seems promising and can serve as a guiding example for similar experiences. However, when looking at the scope of this study it is clear that only few variables have been included to explain employee intrapreneurial behaviour. More variables are needed to establish this interplay.

In addition, the study focused on SMEs in fruit juice processing only. Although there are several theoretical reasons why findings of this study could be generalised to other SMEs, particularly those in the agro food processing industry, testing these hypotheses amongst a larger group of SMEs and possibly in other countries could lead to a more general study findings. Perhaps other studies could embrace all the players in the agro food processing industry to get more insight on the intrapreneurial behaviour of the agro processing industry.

This study is cross sectional and, as such, it cannot be exploited to derive causal effects. The only effect from cross-sectional is mainly observational. An extension of this study; a longitudinal research, could provide further substantial insight on the causality effect of this topic and concept. 


\section{References}

Afriyie N, Nchimbi M, Melyoki LL (2019) Antecedents of intrapreneurial behaviour of Small and Medium enterprises in fruit processing industry of Ghana. $\mathrm{PhD}$ Thesis University of Dar es Salaam repository, Dar es Salaam.

Ahmad NH, Nasurdin AM, Zainal SRM (2012) Nurturing intrapreneurship to enhance job performance: The role of pro-intrapreneurship organizational architecture. Journal of Innovation Management in Small \& Medium Enterprises vol 2012. DOI: $10.5171 / 2012.868880$.

Amo BW (2010) Corporate entrepreneurship and intrapreneurship related to innovation among employees, International Journal of Entrepreneurial Venturing 2:2. Doi: 10.1504/1JEV.2-10.034819.

Antoncic A, Hisrich RD (2001) Intrapreneurship: construct refinement and cross-cultural validation. Journal of Business Venturing 10(3): 495-527.

Antoncic B, Hisrich RD (2003) Clarifying the intrapreneurship concept, Journal of Small Business and Enterprise Development 10(1):7-24. https://doi.org/10.1108/14626000 310461187.

Arbuckle JL (2012) IBM SPSS Amos 21 user's guide. Armonk: IBM Corpoation.

Artino AR (2012) Academic self-efficacy: from educational theory to instructional practice. Perspective Medical Education 1(2):76-85.

Bager T, Ottosson H, Schott T (2010) Intrapreneurs, entrepreneurs and spin-off entrepreneurs: Similarities and difference. International Journal of Entrepreneurship Small Business 10(1): 335-258.

Bandura A (1977) Self-efficacy: Toward a Unifying Theory of Behavioral Change. Psychological Review 84(2): 191-215.

Bandura A (1982) Self-efficacy mechanism in human agency. America Psychologist 37(1): $122-147$

Bandura A (1986) Social Foundations of Thought and Action: A Social Cognitive Theory. Englewood Cliffs NJ: Prentice-Hall.

Bandura A (1997) Self-efficacy: The exercise of control. New York: Freeman.

Bandura A (2001) Social cognitive theory: An agentic. Annual review of psychology 52(1): 26.

Barakat S, Boddington M, Vyakarnam S (2014) Measuring entrepreneurial self-efficacy to understand the impact of creative activities for learning innovation. The International Journal of Management Education 12(3): 456-468.

Barney JB (1991) Firm resources and sustained competitive advantage. Journal of Management 17(1): 99-120.

Baruah B, Ward A (2014) Role of a CEO in adopting intrapreneurship as an organizational strategy in SMEs International Entrepreneurship Management Journal. Doi: 10.100 7/s11365-014-0318-3.

Bateman TS, Crant JM, (1993) The proactive component of organizational behavior: A measure and correlates. Journal of Organizational Behaviour 14(1): 103-118.

Becherer RC, Maurer JG (1999) The proactive personality disposition and entrepreneurial behavior among small company presidents. Journal of Small Business Management 37(1): 28-36.

Bosma N, Stam E, Wennekers S (2011) Intrapreneurship versus independent entrepreneurship: A cross-national analysis of individual entrepreneurial behavior Working Papers 11-04, Utrecht School of Economics. 
Boyd NG, Vozikis GS (1994) The influence of self-efficacy on the development of entrepreneurial intentions and actions. Entrepreneurship Theory and Practice 18(4): 63-77.

Browne MW, Cudeck R (1993) Alternative ways of assessing model fit. In KA Bollen, JS Long (eds) Testing Structural Equation Models, 136-162. Newbury Park, CA: Sage.

Carrier C (1994) Intrapreneurship in large firm and SMEs. A comparative study. International Small Business Journal Researching Entrepreneurship 12(3): 54-61.

Carrier C (1996) Intrapreneurship in Small Businesses: An Exploratory Study. Journal of Entrepreneurship and Practice 21(1): 5-20.

Cetin F (2011) The Roles of Self-efficacy and Locus of Control in the Intrapreneurship. Business and Economics Research Journal 2(3): 69-85.

Choi BY, Park H, Yang E, Lee SK, Lee Y, Lee SM (2011) Understanding career decision self-efficacy: A meta-analytic approach. Journal of Career Development 39(5): 443460. Doi: 10.1177/0894845311398042.

Compeau DR, Higgins CA, Huff S (1999) Social cognitive theory and individual reactions to computing technology: A longitudinal study. MIS Quarterly 23(2) 145-158.

Covin JG, Slevin DP (1986) The development and testing of an organizational-level entrepreneurship scale. Frontiers of Entrepreneurship Research 1(3): 628-639.

Covin JG, Slevin DP (1991) A conceptual model of entrepreneurship as firm behavior. Entrepreneurship theory and practice 16(1): 7-25.

Crant JM (1996) The proactive personality scale as a predictor of entrepreneurial intentions. Journal of Small Business Management 34(3): 42-49.

Davidsson P, Honig B (2003) The role of social and human capital among nascent entrepreneurs. Journal of Business Venturing 18(3): 301-331.

De Massis A, Audretsch DB, Uhlaner L, \& Kammerlander N (2017) Innovation with limited resources: Management Lessons from the German Mittelstand. Journal of Product Innovation Management 35(1): 125-146. DOI: 10.1111/jpim.12373.

Deloitte Global Report (2015) Five insight into intrapreneurship: a guide to accelerating innovations within corporations, White Paper. https://www2.deloitte.com.

Dorner N (2012) Innovative work behaviour: The roles of employee expectations and effects on job performance. Available at: https://www1.unisg.ch/www/edis.nsf.

Drucker PF (1985) Innovation and Entrepreneurship. New York: Harper \& Row.

Edu Valsainas, Moriano JA Molero F (2016) Authentic leadership and intrapreneurship behaviour: cross-level analysis of the mediator effect of organisational identification and empowerment. International Entrepreneurship Management Journal 12(1):131152. http://doi.org/10.1007/s11365-014-0333-4.

Gawke JC Gorgievski MJ, Bakker AB (2017) Employee intrapreneurship and work engagement: A latent change score approach. Journal of Vocation Behaviour 100: 88-100.

Gawke JC, Gorgievski MJ, Bakker BB (2019) Measuring intrapreneurship at the individual level: development and validation of the employee intrapreneurship scale. European management Journal. http://doi.org/10.1016/j.emj.2019.03.001.

Gist ME, Mitchell TR (1992) Self-efficacy: A theoretical analysis of its determinants and malleability. Journal of Academy of Management Review 17(2): 183-211.

Guerrero M, Pena-Legazkue I (2013) The effect of intrapreneurial experience on corporate venturing: evidence from developed economies. International Entrepreneurship Management Journal 9(1): 397-416.

Guth WD, Ginsberg A (1990) Guest editor's introduction: Corporate entrepreneurship. Strategic Management Journal 11(Summer 1990): 5-15.

Hair JJr, Black W, Babin A, Anderson R (2014) Multivariate data analysis: Pearson New International Edition, 7th ed. Essex, NJ: Pearson. 
Heinonen J, Korvela K (2004) How About Measuring Intrapreneurship? Finland: Small Business Institute, Turku School of Economics and Business Administration. www.tu kkk.fi/pki.

Hewitt-Dundas N (2006) Resource and capability constraints to innovation in small and large plants; Journal of Small Business Economics 26(3): 257-277. https://link.sprin ger.com/article/10.1007/s11187-005-2140-3.

Hollenbeck GP, Hall DT (2004) Self-efficacy and leader performance. Journal of Organisational Dynamic 33(3): 254-269. DOI: 10.1016/j.orgdyn.2004.06.003.

Hsu M-H, Ju TL, Yen C-H, Chang C-M (2007) Knowledge sharing behaviour in virtual communities: the relationship between trust, self-efficacy and outcome expectations. International Journal of Human-Computer Studies 65(1): 153-169.

Intrapreneurship conference (2017) Creating, capturing and capitalizing on opportunities for growth Conference proceedings Reuters Africa. Available at: https://africabusi nesscommunities.com.

Jőreskog KG, Sőrbom D (1982) Recent developments in structural equation modeling. Journal of Marketing Research 19(4): 404-416.

Knight GA (1997) Cross-cultural reliability and validity of a scale to measure entrepreneurial orientation. Journal of Business Venturing 12(3): 213-25.

Kothari CR (2014) Research Methodology: Methods and Techniques, 2nd rev. ed. New Delhi: New Age.

Lumpkin GT, Dess GG (1996) Clarifying the entrepreneurial orientation construct and linking it to performance. Academy of Management Review 21(1): 135-172.

Mathieu JE, Taylor SR (2006) Clarifying conditions and decisions points for meditational type inferences in organisational behavior. Journal of Organisational Behaviour 27(8): 1031-1056.

Mohd N, Maat SM, Mat SC (2015) A study on entrepreneurial intention among engineering technology students. Mediterranean Journal of Social Sciences 6(4): 348-355.

Mokaya SO (2012) Corporate entrepreneurship and organizational performance: theoretical perspectives, approaches and outcomes. International Journal of Arts and Commerce 1(4): 133- 143.

Moriano J, Molero F, Topa G, Levy-Mangin JP (2014) The influence of transformational leadership and orgagnisational identification on intrapreneurship. International Entrepreneurship and Management Journal 10(1): 103-119.

Morris HH (2001) Entrepreneurial Intensity: Sustainable Advantages for Individual Organisations and Societies. New York: Qurom Books.

Motlagh SE, Amrai K, Yazdani MJ, Abderahim HA, Souri H (2011) The relationship between self-efficacy and academic achievement in high school students. Journal of Procedia Social and Behavioural Sciences 15(1): 765-768. http://doi:10.1016/j.sbs pro.2011.03.180.

Mugenda OM, Mugenda AG (2010) Research methods: Quantitative and Qualitative Approaches, $4^{\text {th }}$ ed. Nairobi: Acts Press.

Muretta RJ (2005) Exploring the Four Sources of Self-Efficacy. Touro: Touro University International, Dissertation.

Mustafe M, Martin L, Hughes M (2016) Psychological ownership job satisfaction and middle manager entrepreneurial behaviour. Journal of Leadership and Organisational Studies 27(3): 272-287.

North JJ (2015) Individual intrapreneurship in organisations: a new measure of intrapreneurial outcomes. PhD Thesis, University of New York, NY. 
Pajares F, Graham L (1999) Self-efficacy, motivation constructs and mathematics performance of entering middle school students. Contemporary Educational Psychology 42(1): 190-198

Park SH, Kim J-N, Krishna A (2014) Bottom-up building of an innovative organisational motivation employee intrapreneurship and scouting and their strategic valve. Management Communication Quarterly 28(4): 531-560.

Parker SC (2011) Intrapreneurship or entrepreneurship? Journal of Business Venturing 26:19-34. http://doi.org/10.1007/j.jbusvent.200.9.07.003.

Peng WL, Jie J, Naiqiu L, Zhengzhong X (2010) A review and prospect of research on human resources management of intrapreneurship. ASBN: 978-1-4244-6932-1. DOI: 10:1109/ICAMS.2010.5553199.

Penrose E (1959) The theory of the growth of the firm, Oxford: Blackwell. In TJ Peters, RH Jr Waterman (1982) Search of Excellence. New York: Harper \& Row.

Pinchot G (1985) Intrapreneuring in Action. A Handbook for Business Innovation. Berrett-Koehler Publishers.

Pinchot G (1999) American Heritage Dictionary of the English Language, 3rd Edition Ten Steps to an Entrepreneurial Organization Rule, Erik G., and 19.

Pinchot G, Pinchot E (1978) Intra-Corporate Entrepreneurship, Tarrytown School for Entrepreneurs. Available at: http://www.intrapreneur.com.

Rigtering JPC, Weitel UTZ (2013) Work context and employee behaviour as antecedents for intrapreneurship. International Entrepreneurship Management Journal 9(3):337360.

Rogue F, Soares S, Breitenfeld L, Gonzalez-Gonzalez C, Figueiras A, Herdeiro MT (2014) Portuguese community pharmacists' attitudes to and Knowledge of antibiotic misuse: Questionnaire development and reliability. PLoS One 9(3): e90470. Doi: 10.1371/ journal.phone.0090470.

Saunders M, Lewis P, Thornhill A (2012) Research methods for business students (6th ed). London: Pearson.

Schawbel D (2013) Why companies want you to become an intrapreneur Available at: https:// www.forbes.com/sites/danschawbel/2013/09/09/why-companies-want-youto-become-an-intrapreneur/.

Schollhammer H (1981) The efficacy of internal corporate entrepreneurship strategies. In KH Vesper (ed) Frontiers of Entrepreneurship Research, 45 1-6. Wellesley, MA: Babson College.

Schumpeter JA (1939) Business Cycles, vol.1. New York: McGraw Hill.

Sharma. P, Chrisman JJ (1999) Toward a reconciliation of the definitional issues in the field of corporate entrepreneurship. Entrepreneurship Theory and Practice 23 (3):1127.

Sijde P, Veenker S, During W (2013) Intrapreneurship in SMEs: about the role of management and R\&D. European Journal of Business and Social Sciences 1(11) 2430.

Stam E (2013) Knowledge and entrepreneurial employees: a country-level analysis. Journal of Small Business Economics 41(4): 887-898.

Stam E, Stenkula M (2017) Intrapreneurship in Sweden: an International perspective. Available at: http://www.projectfires.eu/wp-contents.

Stevenson HH, Jarillo JC (1990) A paradigm of entrepreneurship: entrepreneurial management. Strategic Management Journal 11(4): 17-27.

Sun L-Y, Pan W (2011) Market Orientation, intrapreneurship behaviour and organisational performance: Testing of a Structural Contingency Model. Journal of Leadership and Organisational Studies 18(2): 274-285. 
Taştan SB, Güçel C (2014) Explaining intrapreneurial behaviors of employees with perceived organizational climate and testing the mediating role of organizational identification: A research study among employees of Turkish innovative firms. Procedia - Social and Behavioral Sciences 150: 862-871.

Urban B Oosthuizen JH (2009) Corporate entrepreneurship, firm innovation, intrapreneurship, leadership and Mining industry. Journal of Contemporary Management 6(1): 170-192.

Urbano D, Alvarez C, Turro A (2013) Organisational resources and intrapreneurial activities: an international study. Journal of management Decision. http://doi.org/10. 1108/00251741311326617.

Usher EL, Pajares F (2006) Sources of academic and self-regulatory efficacy beliefs of entering middle school students. Contemporary Educational Psychology 31(2): 125141.

Vargas-Halabí T, Mora-Esquivel R, Siles B (2017) Intrapreneurial competencies: development and validation of a measurement scale. European Journal of Management and Business Economics. https://doi.org/10.1108/EJMBE-07-2017-006.

Vroom VH (1964) Work and Motivation. New York: John Wiley.

Wakkee I, Elfring T, Monaghan S (2010) Creating entrepreneurial employees in traditional service sectors: The role of coaching and self-efficacy. International Entrepreneurship and Management Journal 35(5): 895-923.

Woo HR (2018) Personality traits and intrapreneurship: The mediating effect of career adaptability. Career Development International Journal 23(2): 145-162.

Wood R, Bandura A (1989) Social congnitive theory of organisational management. The Academy of Management Review 14(3): 361-384.

Yuan F, Woodman RW (2010) Innovative behaviour in the workplace: The role of performance and image outcome expectations. Academy of Management Journal 53(2): 323-342.

Yusuf M (2011) The impact of self-efficacy, achievement motivation, and self-regulated learning strategies on students' academic achievement. Journal of Procedia Social and Behavioural Sciences 15: 2623-2626. http://doi:10.1016/j.sbspro.2011.04.158.

Zahra S (1993) A conceptual model of entrepreneurship as firm behavior: A critique and extension. Entrepreneurship Theory and Practice 17(4): 5-21. 
